\title{
Thuma mina! Who Sends Whom? How South Africa as a Rainbow Nation has been Perceived in the Church of Sweden
}

\section{Anders Göranzon}

\section{Abstract}

The Church of Sweden has a relationship with South Africa stretching back to around 150 years ago. From the start, the focus was to do Christian mission work in South Africa, through the Church of Sweden Mission. The relationship has been described as 'mutual', because the Church of Sweden was also learning from South Africa's indigenous Christians, about the gospel itself, but also about the critical interpretation of Scripture with regard to social, and political problems. This article looks at the period from 1994 to date, and evaluates the nature of the aspects of the relationships between the Church of Sweden and its partners in South Africa. Special focus is given to issues like economic and social justice, HIV and AIDS, the Zimbabwean crisis, the arms deal, and the reconciliation process. The Church of Sweden has sometimes gained experiential insights and inspiration from South Africa - which has proven valuable in the local, Swedish context. In other cases, the influence of the South African churches on the Church of Sweden is less tangible. On national level, in recent years, the Church of Sweden has put the emphasis on aid and development in South Africa, and shown less interest in inter-Church relations. The longstanding relations with especially the Evangelical Lutheran Church in Southern Africa is now a responsibility of some Dioceses in the Church of Sweden, and not of the national body anymore. This could mean too, that the mutuality aspect of the relationships with South African churches, but also more broadly, with the South African socio-political situation, is in the process of undergoing certain changes.

Keywords: Mutuality, mission, South Africa, Sweden, relations 


\section{Introduction}

In 1986 the chorus, Thuma mina, was included in the hymnbook of the Church of Sweden (Svenska kyrkan 1986:584). Swedish civil society - the churches included, as was the case in other Scandinavian countries - was at the time involved in the struggle against apartheid. Different church-based exchange programs led to this concrete sign of partnership, among many others. Even today, one can sometimes hear these Nguni words sung in an ordinary church service in Sweden. From the Church of Sweden $(\mathrm{CoS})$ point of view, it was therefore natural to associate the South African State of the Nation Address (2018) with its theological and biblical, narratives as these have developed in interaction with South Africa.

It was especially after the 1976 student uprisings in South Africa, against apartheid, that the Church of Sweden Mission (CSM) became involved in youth work within the Evangelical Lutheran Church in Southern Africa (ELCSA). The ELCSA Youth League has a motto taken from the book of Isaiah 6:8b: 'Here am I Lord, Send me' (ELCSA:3.1) ${ }^{1}$. The fact that President Cyril Ramaphosa grew up as a member of ELCSA has not passed unnoticed:

Ramaphosa's strong religious context growing up in the Student Christian Movement (SCM) in the University and being a member of the Evangelical Lutheran Church [of] Southern Africa (ELCSA) was evident in the thuma mina moment and he appears to understand the important role of the ecumenical faith movement in the realization of the 'thuma-mina' moment in South Africa (Zwane 2018).

The President's call for involvement does not stop at the border of South Africa. Based on the thuma mina reference, this article sets out to answer how $\mathrm{CoS}$ has been influenced by the relationship with the Church and society in South Africa more broadly speaking. Its point of departure, however, is the question about how South Africa's democratisation process has been perceived in $\mathrm{CoS}$ over the years. In focus is the concept of mutuality.

There has been a shift in missiological perspectives in the latter part of the twentieth century which amongst others have manifested in the World Council of Churches document: Together Towards Life: Mission and

${ }^{1}$ In isiZulu, isiXhosa and isiNdebele the words 'Send me' translate into 'Thuma mina'. 
Evangelism in Changing Landscapes. I want to use this as a framework in my analysis of how CoS might have gained something from its engagement in South Africa and not only contributed to South Africa. In one of the paragraphs, the mission document states that 'people at the margins are claiming their key role as agents of mission and affirming mission as transformation' (World Council of Churches 2013:5). It is however worth noting that the Together Towards Life document only uses the word mutual once. In that instance it has to do with the relation between 'our participation in mission, our being in creation, and our practice of the life of the Spirit' (World Council of Churches 2013:21).

Church of Sweden's International Department's own steering documents on the other hand stresses mutuality as an important part of its international work. 'The Church of Sweden shares its mission with other churches and wants to perform it in mutual partnership, based on affinity and continuous learning' (Church of Sweden International Department 2013:5). The question is: has $\mathrm{CoS}$ understood that it also has something to learn from the relation with for instance its partners in South Africa? This is the main research question of this article.

Being a Faith Based Organisation, CoS has hopefully been contributing to good practices in South Africa and has also been influenced by South African good practices. When the South African society has sought to realise and implement the principles of its constitution, by many regarded as one of the most progressive in the world, the question arises: has this also influenced Sweden? Or put differently - like the topic of this article: who sends whom?

In order to discern the areas where this learning might have taken place I will first look at how the first 25 years of democratisation in South Africa have been perceived by $\mathrm{CoS}$. I have looked at reports from $\mathrm{CoS}$ ' co-workers deployed in South Africa. Those are traditional missionaries that have worked in ELCSA, co-workers seconded to other partners, as well as office personnel stationed in South Africa. Reports are written either monthly, over a period of three months, yearly, or at the end of the mission.

Church of Sweden Mission (CSM) was formed in 1874. The first missionaries were sent to Zululand in 1876 (Fosseus 1974:12). For more than a century CSM continued to work within structures that only changed marginally. CSM was not a traditional mission society. From the beginning it was an integrated part of CoS which was a State Church (Björck 2014:33). When CoS cut its ties with the state in 2000, CSM also changed and after a few 
years merged with Church of Sweden Aid.

Methodologically the initial idea was to look at annual reports from the CSM or the international department of CoS. The format of the reports has however changed over the years and it is only in the beginning of the period possible to clearly answer the questions how South Africa's democratisation process has been perceived by CoS. More recent reports are organised thematically. This is the reason for choosing missionaries' or co-workers' reports as the major source. It has to be said from the outset that they do not contain the official standpoint of CoS. In some cases, there will nevertheless be a few references to annual reports of the CSM as a whole.

The structure of the article will be thematic. First there will be a general section on the South African transformation process and how this has influenced the relation between $\mathrm{CoS}$ and South Africa. Thereafter the article will look at issues like social justice, HIV and AIDS, the Arms Deal, South Africa's policy on the Zimbabwe issue, the Truth and Reconciliation Process, and the concept Mission to in return. Every section will elaborate on how South Africa has been described in the reports but also how CoS has been or has not been influenced by its engagement in South Africa in relation to the specific theme.

\section{The Transformation}

Just as the South African Council of Churches (SACC), one of CoS' longstanding partners in South Africa, had to find a new focus when the struggle against apartheid had ended (Göranzon 2010:28) the same could be said about CSM. The work that CSM, its missionaries and Church of Sweden Aid were involved in, had over the years, in one way or another, become more and more linked with the struggle against apartheid. When the whole South African society went through a time of transformation it goes without saying that $\mathrm{CoS}$ too, had to refocus in South Africa. From the material it is clear that both CSM as an organisation and the co-workers entered this new era with high expectations.

As already stated the major source of information will be co-workers' reports. It is however of interest to look at a few annual reports of the CSM, when an analysis of the situation in South Africa is still part of the format.

In 1994, the annual report of CSM focuses on the general election. It 


\section{Anders Göranzon}

describes the fear of violence that were there before the elections. It is especially pointed out that Nelson Mandela and others in the ANC have shown understanding for the white right-wing groups, who have demanded a homeland of their own, as well as for the demands from the Zulu, for a kingdom of their own. The report uses the word 'miracle', to describe the peaceful manner in which the elections were held:

The portrayal of the elections as a miracle figures in wide circles to emphasise that it cannot be explained unless a higher power has helped South Africa [my translation] (CSM 1994:13) ${ }^{2}$.

When co-workers write and submit their reports to the sending organisation, expressions of high expectations are intertwined with examples of disturbing signs that the new dispensation, from the start led by the iconic Madiba, will not be able to meet those expectations. One report's comment from 2006 sums it up:

To live in South Africa is contradictory. One continues to be thrown between hope and resignation, between confidence that reconciliation and democracy will prevail and that the problems are too huge to be solved, and that the greed and egoism of people will get the upper hand [my translation] (2006:1, page 1$)^{3}$.

At the same time, individual missionaries, just like CSM as an organisation, describe the process as a miracle $(1994: 4 ; 1997: 1)$ or as a 'divine intervention' (1994:4, page 1). The missionaries look back to this event also in reports after a few years of democracy. One report wants to underscore that it is,

... important, in the middle of all negative international publicity about

\footnotetext{
2 'Beskrivningen av valet som ett mirakel förekommer i vida kretsar för att betona att det inte kan förklaras, utan att det är en högre makt som har hjälpt Sydafrika'

3 'Att leva i Sydafrika är motsägelsefullt. Man fortsätter att kastas mellan hopp och uppgivenhet, mellan tro på att försoning och demokrati ska segra och att problemen är alltför stora att lösa och att människors girighet och egoism ska ta överhanden'.
} 
South Africa, to remember what has been achieved with its peaceful transformation and that building functioning structures and institutions takes time (2001:4, page 3).

Going back to reports from 1993-1994. it is obvious that not everyone would describe the transformation process as peaceful. Terms like 'third force' (1993:1) and 'civil war' (1994:2; 1997:1) are being used. One report comments on the situation: 'Even if I was careful and avoided areas I knew to be dangerous, the uncertainty of living in a very volatile situation was at times very trying' (1994:2, page 3). Another report portrays another view and states that 'we always felt that we could move freely, reach people and do our job' (1994:4, page 1). Generally speaking, the reports show understanding, when it comes to the complexity of the issues that the new dispensation and the nation at large had to deal with.

The expectations of the Church were high. 'The church has had and will continue to have an important role as a watchdog for human rights and democracy related issues in the new dispensation' (1994:4, page 4). This is a common theme in the work of the South African Council of Churches too (Göranzon 2010:418). This is however based on the assumption that the new Government has good intentions.

After a year of euphoria following the democratic elections in South Africa, the past two years have been characterised by the struggle of the government of national unity to get efficient management structures established within the national and provincial civil service - an important precondition for being able to deliver on the election promise of 'a better life for all' (1997:2, page 1).

\section{Social and Economic Justice}

If we first have a look at some annual reports of the CSM, the Reconstruction and Development Programme (RDP) is mentioned as an example of the effort of the Government of National Unity (GNU). In this context, the role of the churches is enforced when it comes to implementation. Especially is the role of the SACC, highlighted by leaders such as Frank Chikane and Brigalia Bam. At the same time, one of the reports notes that church leaders are recruited to political leadership roles. This is seen as a challenge for the churches. 
On poverty, in 1995 it is stated, only in passing, that the gap between rich and poor amongst blacks are widening (CSM 1995:18-19). In 1996 the economic situation is described in a pessimistic way: 'The poor see no improvement and the government admits that its reconstruction programme has failed [my translation]' (CSM 1996:165) ${ }^{4}$.

In the co-workers' reports a number of aspects of the deep-rooted injustices that belong to the legacy of apartheid and colonialism are part of the main message of most reports. In the beginning of the period the RDP is being highlighted (1994:2;1994:4; 1995:2;1996:2; 1997:1; 2004:1). In 2005, one co-worker reports about how,

Finance Minister Trevor Manuel was invited to give a speech when a number of RDP houses, in one of the Northern Provinces, were to be handed over to the community. When he entered one of the houses he could, with his own eyes, discover that the house was built carelessly. Of course, he started an investigation, but how many other RDP house schemes are faced with the same problem? (2005:1, page 2).

Almost every report refers to inequality. Twelve years after the democratic elections, one report summarises the situation and finds that 'little of the prosperity has "trickled down" to the majority of the previously disadvantaged population' (2006:7, page 2). Injustice exemplified with unemployment, is the most frequent theme of the reports $(1995: 2 ; 1997: 1 ; 1997: 3 ; 1999: 1 ; 1999: 2$; 2001:2; 2001:3; 2001:4; 2003:1; 2003:2; 2004:2; 2006:2).

There are a few examples when the Government's ability to implement its policies are being described positively. One report states that ' $[\mathrm{h}] \mathrm{louses}$, clinics and schools have been [built], school children are being fed' (1999:2, page 2). Another report claims that social welfare systems are working (2003:1). One report underlines that the ANC 'strives for a more just distribution of wealth but the criticism that the pace is too slow grows stronger [my translation]' (2006:6, page 1$)^{5}$. The problem, state other reports, is often the implementation (2005:1). One report is pointing to the fact that many

\footnotetext{
4 'De fattiga ser ingen förbättring och regeringen erkänner att dess rekonstruktionsprogram har misslyckats'.

5 'Budget för budget strävar ANC mot en rättvisare fördelningspolitik men kritiken att det går för långsamt blir allt starkare’.
} 
households rely on the income of one pensioner and mentions the Basic Income Grant (BIG) as one way of easing the burden of such families (2001:5). The land issue is also being referred to as a challenge in the search for a more equal society (2003:1, 2006:6). Another concern mentioned, is the issue with high school fees $(2004: 2 ; 2006: 1)$.

$\mathrm{CoS}$ has also, as an organisation, focused on issues of economic and social justice. The support to SACC and ELCSA has diminished and instead other partners (most of them still ecumenical organisations) have come into play. Contemporary examples are the Economic Justice Network (EJN), the Southern African Faith Communities' Environment Institute (SAFCEI), the Institute for Healing of Memories (IHOM), and the Philani Maternal, Child Health and Nutrition Trust (2014:3). CoS has also in recent years worked in partnership with the University of KwaZulu-Natal (UKZN) and Stellenbosch University (SUN), especially in supporting a Master Programme named Gender, Health and Theology (Stellenbosch University 2015) or Gender, Religion and Health (University of KwaZulu-Natal 2014).

In a report to the Church Board in February 2019, the CoS General Secretary highlights the advocacy work in the mining section by Bench Marks Foundation and SAFCEI (Church of Sweden. General Secretary's Report. 2019:7). There are few signs that CoS has utilised experiences gained in South Africa in the work for economic and social justice in Sweden.

\section{Specific Themes}

A few years after the first democratic elections, the co-workers start to express words of criticism. The reports are not always in agreement. In 2001, one report signals a development that freedom of speech is becoming cropped (2001:4) while other reports state the opposite and claim that media may act freely (2002:1; 2006:1). During the second Mbeki term, critique is also directed at the President from the missionaries. One report mentions three embarrassments of the Mbeki administration: HIV/AIDS, Zimbabwe, and Jas Gripen ${ }^{6}$ (2002:1). In fact, these three issues are recurrent themes in the reports.

Interestingly enough two of these issues are mentioned in a report from a Popular Movements' Meeting held in 2008 in Sweden. The gathering sought

${ }^{6}$ Jas Gripen is a Swedish warplane, and refers to the Strategic Defence Package or the Strategic Defence Acquisition, popularly referred to as the Arms Deal. 
to evaluate what Swedish Civil Society had learnt from its participation in the struggle against apartheid. Some priorities for the future were mentioned in the report. HIV and AIDS as well as Zimbabwe were two of them but nothing was said about the arms deal in general or Jas Gripen in particular (Modern Solidarity 2008:3).

\section{HIV and AIDS}

The reports are especially concerned with the health situation in the country. Even in this respect the expectations are high and the Swedish co-workers are hopeful:

... with a new government in sight in South Africa, we are hoping for a national health system with significant resources being channelled towards primary health care and child nutrition in those areas which has previously been neglected (1993:1, page 5).

The AIDS pandemic is mentioned in almost every report from 1999 and onwards. Antiretrovirals in general and the actions by the Treatment Action Campaign (TAC) are also examples, which the co-workers want to give attention to $(2001: 1 ; 2001: 2 ; 2001: 3 ; 2002: 1 ; 2003: 2)$. The reports are concerned with the unwillingness of Thabo Mbeki to deal with HIV and AIDS in a serious way. 'President Thabo Mbeki's yearly State of the Nation Address ... aroused some criticism, inter alia that he did not speak so much about Aids [my translation]' (2003:1, page 1) ${ }^{7}$. There is an echo of the high expectations mentioned earlier, when one of the reports blurts out:

The feeling of victory when powerful pharmaceutical firms had to withdraw from their court case against the South African government, attempting to challenge their decision not to abide by patent laws regarding antiretrovirals, turned to despondence and bewilderment when the same government appealed against a court decision requiring all public health services to provide antiretrovirals to

7 'President Thabo Mbekis årliga tal till nationen hölls vid parlamentets öppnande vilket väckte en del kritik, bl.a. för att han inte talade så mycket om Aids'. 
pregnant mothers in order to prevent transmission of HIV to the child (2001:4, page 1-2).

Another aspect of the AIDS pandemic that come to the fore is the stigma that is related to the disease $(2004: 2 ; 2005: 1 ; 2006: 1)$.

A visible sign that South Africa has influenced CoS regarding HIV and AIDS is the Pastoral Letter from the Bishops of the Church of Sweden about HIV from a Global Perspective. Even if the Pastoral Letter admits that the epidemic affects numerically more people in Southern Africa, than elsewhere, it states that it is also a challenge 'in Sweden, despite worrying tendencies to trivialise the problem because of its relatively small scale' (Church of Sweden Bishops' Conference 2007:43). Church of Sweden's International Department has for more than a decade had a staff member employed to work with issues around HIV. Today an Anglican priest from South Africa, Rev. Johannes Petrus (JP) Mokgethi-Heath, is employed in Sweden to work as Policy Advisor on HIV, Human Sexuality and Theology (Outrage). Through the issue of HIV, $\mathrm{CoS}$ has gained some broader learning in the field of Sexuality. This is an outcome of CoS presence in South Africa over a number of years. This is not surprising, as South Africa, in some areas, have been a forerunner in HIV/ Aids interventions. For instance, South Africa granted legal recognition to same-sex marriages in 2006, while Sweden did the same only in 2009 (Pew Research Centre 2017).

\section{Zimbabwe}

Another issue that a number of reports touch on, is the policy of the ANC-led Government of South Africa about the situation in Zimbabwe. While this is frequently mentioned $(2001: 4 ; 2001: 5 ; 2002: 1 ; 2003: 1 ; 2003: 2 ; 2004: 1$; $2005: 3$; 2005:5) there are few signs of a deeper analysis, with one exception, when the absence of action from the side of the South African Government is interpreted as silent diplomacy (2003:1). A controversial trip to Zimbabwe by the COSATU leadership in 2004, is also highlighted (2004:1).

One question that arises, is the standpoint of $\mathrm{CoS}$ when it comes to South Africa's government's policy on the Zimbabwe crisis. One assumption is that $\mathrm{CoS}$ has focused on its own partnership with the Evangelical Lutheran Church in Zimbabwe (ELCZ). This Church has also been careful in its critique of the Zimbabwean Government, unlike the Zimbabwe Council of Churches, 
which has issued statements about the political situation in Zimbabwe (Zimbabwe Council of Churches 2009). CoS is involved in Zimbabwe through a twinning relation that Uppsala Diocese and ELCZ has had since 1998 (Uppsala stift 2019). This relation can be seen as support to the Zimbabwean people. The bishop of Uppsala Diocese writes in connection with the centenary of ELCZ 2003: 'This Centenary is being celebrated at a time of anxiety and insecurity and we have to support one another in the prayer that God will help us and bring us liberation' (Persenius 2003:5). In this context, the cost of raising one's prophetic voice in Zimbabwe is much higher than in Sweden.

\section{Jas Gripen}

Corruption is described in general terms, the first years after the transition into democracy $(1997: 2 ; 1999: 2 ; 2000: 1 ; 2001: 5)$. 'Freedom has been interpreted as freedom to take one's share by force' (1997:3, page 2). Later on, it is often linked to Jacob Zuma $(2004: 1 ; 2006: 6 ; 2006: 7)$. One aspect is the alleged involvement of Jacob Zuma in the arms deal. This is also particularly mentioned in some of the reports. Especially around the turn of the millennium, the arms deal is surfacing as an issue in more than one report. In several of those, the authors are rather outspoken and it is of special interest when the Swedish aircraft Jas Gripen is mentioned. According to one report '[c]ritical voices could be heard just after the decision, but today there are no questions' (2002:1, page 2). In the reports, however, there are signs of criticism in relation to $\mathrm{CoS}$ itself. One report states: 'As Sweden is part of this deal delivering arms to South Africa it is an issue that should be of great concern to the Church of Sweden and the Swedish public' (2003:2, page 1). Another contemporary report regards it as 'odd that Church of Sweden has not more actively spoken out on the subject and supported the local organizations that question the arms purchase [my translation]' (2003:1, page 7$)^{8}$.

There are reasons for the silence of $\mathrm{CoS}$ that the co-workers experience. This does not mean that other organisations in Sweden were silent. One of the first debates in Sweden around the Jas Gripen component in the South African arms deal took place in the magazine Broderskap, journal of the Christian Social Democrats in Sweden. The Archbishop of CoS, K.G. Hammar, questioned the counter-purchase arrangement. Ironically K.G.

8 ‘... märkligt att Svenska kyrkan inte mer aktivt uttalat sig i ämnet samt stött de lokala organisationerna som ifrågasätter vapeninköpet'. 
Hammar had been part of the Isolate South Africa Campaign during the struggle against apartheid and he was now accused of proposing sanctions once again, even though South Africa had become a democracy (Resare 2010: 109-110). Hammar later published a debate article, together with amongst others, former Archbishop Desmond Mpilo Tutu, in one of the leading Newspapers in Sweden (as well as in other newspapers around the world). In this article the arms deal is linked with the AIDS pandemic.

South Africa purchased weapons and arms that the country did not need, at a cost of SEK 66 billion according to fresh calculations, and Jas Gripen was the single largest expenditure item. Equipment that today barely is used. This took place during the same timespan when the South African Government claimed that it could not afford to provide almost six million South Africans who were sick with hiv/aids, with antiretrovirals and health care [my translation] (Tutu et al. 2012) .

The connection between the arms deal and HIV and AIDS was also made by Zackie Achmat, deputy general secretary of the Treatment Action Campaign (TAC) in an article a few years later (Achmat 2008).

As part of an initiative named the Gothenburg Process, the South African Council of Churches, together with the Christian Council of Sweden, the Coalition for Defence Alternatives (South Africa), and the Fellowship of Reconciliation (Sweden) had already on 9 December 1999 issued a joint declaration, where they called upon the South African Government 'to demonstrate its commitment to fighting poverty and corruption' by following a number of recommendations (The Christian Councils of South Africa and Sweden 2009:75-78). Likewise, the Swedish Government and Saab was called upon to,

... cooperate fully in these inquiries, to suspend the sale of arms to

9 'Sydafrika köpte vapen och krigsmateriel som landet inte behövde för 66 miljarder kronor enligt färska beräkningar, där Jas Gripen var den enskilt största utgiftsposten. Utrustning som i dag knappast används. Detta skedde under samma tidsperiod som Sydafrikas regering uppgav att den inte hade råd att förse de nästan sex miljoner sydafrikaner sjuka i hiv/aids med bromsmediciner och sjukvård'. 
South Africa until the review process is complete, and to urge the British, German, and Italian governments and suppliers to take similar action (The Christian Councils of South Africa and Sweden 2009: 7778).

Church of Sweden supported the Gothenburg Process but it has never made any resolutions concerning the arms deal. One reason might be that the major political parties of the Swedish parliament also form so-called nomination groups in the elections to the Church Assembly. As the Assembly appoints the Central Board, this means that the Central Board commissioners have loyalties to different political parties. Statements on delicate political matters are often done through the Christian Council, of which $\operatorname{CoS}$ is a member. This raises questions about the mutuality in the relationship between $\mathrm{CoS}$ and its South African partners. But it could also be seen as a parallel to the way ELCZ acts in Zimbabwe, being silent about the political situation, while the ZCC makes resolutions.

\section{Reconciliation}

The most evident area where South Africa has inspired the rest of the world, has to do with the Truth and Reconciliation Commission (TRC), which also surfaces in the reports. From 1996 and a few years thereafter, the work of the TRC is mentioned $(1996: 2 ; 1997: 2 ; 1999: 2)$. There are some critical voices saying that not a few 'have the opinion that the TRC was not a success' and in 'general the population is quite tired of the TRC ...' (1999:1, page 3). In another report the focus is on how material about former President F.W. de Klerk was censured in the final report, and also that the report was delayed due to conflicts with Inkatha and Minister Mangosuthu Buthelezi (2003:1).

A distinct example where this influence on Swedish conditions is acknowledged is in the reconciliation process between the Sami and CoS. One of the publications that was part of this process refers to other reconciliation processes in the world and states: 'The most well-known example is the Truth and Reconciliation Commission in South Africa [my translation]' (Johnsen 2017:102 $)^{10}$. The Bishop of Härnösand Diocese, which has a twin Diocese in South Africa, writes about this:

10 'Det mest kända exemplet är Sannings- och försoningskommissionen i Sydafrika'. 
Twin Diocese contacts have also contributed - with people and churches that have lived under oppression. Härnösand Diocese has had such contacts with the church in Slovakia and in South Africa. Chris Hendricks and Michael Lapsley have been important resources [my translation] (Tyrberg 2011:52) ${ }^{11}$.

A contemporary example that stands out is the work of Försoningsgruppen (the Reconciliation Group). Rev. Ulrica Fritzon (CoS) is certified in The Restorative Justice Method at Pollsmor Correctional Services, Cape Town, South Africa, by Hope Prison Ministry (Försoningsgruppen). The organisation wants to utilise this method in Swedish prisons.

\section{Church Relations}

Between 2004 and 2008 the Church of Sweden International Departments Head office instructed the co-workers to answer the question: 'What do you bring back to Sweden?' Even if this has not been the instruction in former reports, it is still elaborated on by some. One report mentions how learnings can be drawn from the youth work. The report is 'impressed by ELCSA's very good structure for the youth that we find in some parts, [and] is far ahead of our Swedish' (2002:2, page 1).

A number of reports mention the concept of Mission in return which Church of Sweden a few years earlier had plans to implement on a broader scale $(2005: 1 ; 2006: 4 ; 2006: 7 ; 2007: 1)$. This project in deed has to do with mutuality:

I hope for Mission in return to be a reality again. I see the need we have in Sweden of having people come here and work together with us, broadening our perspectives and share their experiences [my translation] (2006:4, page 6) ${ }^{12}$.

\footnotetext{
${ }^{11}$ Vänstiftskontakter har också bidragit - med människor och kyrkor som levt under förtryck. Härnösands stift har haft sådana kontakter med kyrkan i Slovakien och i Sydafrika. Chris Hendricks och Michael Lapsley har varit viktiga resurser'.

12 'Jag hoppas att mission i retur kan bli verklighet igen! Jag ser behoven vi har i Sverige av att människor får komma hit och arbeta tillsammans med oss, vidga våra perspektiv och dela erfarenheter'.
} 
In the annual report of 1997 , one can read about this project. One theologian from India, two co-workers from the Church of South India, and one advisor from Costa Rica had been working in Sweden for shorter or longer periods, as part of the project (CSM 1997:113). One person from South Africa who was also part of the project, namely Chris Hendricks, has already been mentioned. Hermansson problematizes the expression Mission in Return and states that it restricts the mission concept to be only geographical (Hermansson 1999:187). Nevertheless, he concludes that Mission in Return is an important ambition for the future of $\mathrm{CoS}$ and argues for a two-way communication in the world-wide church (Hermansson 1999:189). Björck informs us that the project was closed down after a short period, and explains,

The project aimed at facilitating exchange positions from partner churches and was not altogether easy to adjust to the Church of Sweden structure [my translation] (Björck 2014:19) ${ }^{13}$.

One report exemplifies the things that Sweden can learn from South Africa with the terms 'transformation' and 'reconciliation' (2005:1). Having said this, the co-workers still experience a sense of mutuality in their daily work and in the contexts they are part of, being representatives of Church of Sweden in another part of the world. One co-worker formulates it as follows:

Its long-standing and faithful support ... bears witness to the fact that we are part of the world-wide church and one in Christ despite living in different parts of the world, and under different circumstances (2006:7, page 4).

The inspiration that can be drawn from South African Christianity is appreciated but also challenged in one of the reports. Answering the question: 'What do you find with partners that you lack in Church of Sweden?' one co-worker writes: 'An obvious faith and trust in God which at times pacifies but mostly is an asset [my translation]' (2007:1, page 6$)^{14}$. The same report continues:

13 'Projektet byggde på att bereda utbytestjänster för personer från systerkyrkorna och var inte alldeles lätt att passa in i den svenskkyrkliga strukturen'.

14 'En självklar tro på och tillit till Gud som ibland passiviserar men för det mesta är en tillgång'. 
In Southern Africa there lies hidden an ethical, anthropological model which could strengthen the Church not only here but also in Sweden. Among other things, it has to do with our understanding of the human being as an individual and as part of a collective; about an understanding of the incarnation which truly can allow God to take flesh in the world; about possible reconciliation, that can deepen the new testament [my translation] (2007:1, page 6) ${ }^{15}$.

\section{Twin Dioceses}

Two twinning relations involving Church of Sweden and Dioceses in Southern Africa have already been mentioned: Uppsala Diocese and ELCZ have such a relation. Härnösand Diocese likewise is in a twinning relation with Cape Orange Diocese in ELCSA. Church of Sweden is also linked to the South Eastern Diocese of ELCSA through Skara Diocese and to the Eastern Diocese of ELCSA through Göteborg Diocese. In some of these relations, exchange programmes are in place. When CoS's national level focuses on humanitarian aid and advocacy work, the aspect of the Church's relations will continue though these relations. It could be an area for further studies to see how the learning has taken place on the Swedish side. Strinnholm writes about these questions but the area of study is the relation between $\mathrm{CoS}$ and the Evangelical Lutheran Church in Tanzania (ELCT). In the introduction she refers to a visit by Härnösand Diocese to its twin diocese in South Africa though. In a discussion among the Swedish delegates, questions were asked whether or not they were buying friendship with the South African partner diocese, when a donation for a Church Building was the main reason for the visit (Strinnholm 2016:5). This touches on the problem with the exchange of money. There are however other avenues. One report suggests that the CoS Dioceses and their twin Dioceses in Southern Africa could embark on mutual learning journeys with joint courses around different topics, e.g. migration (2015:1).

15 'I södra Afrika finns dolt en etisk, antropologisk modell som skulle kunna stärka kyrkan inte bara där utan också i Sverige. Det handlar bl a om vår förståelse av människan som individ och kollektiv; om en förståelse av inkarnationen som på allvar kan få Gud att ta kropp i världen; om möjlig försoning som kan fördjupa det nya förbundet'. 


\section{Conclusion}

The question about what CoS has learned from its relationship with ELCSA, the ecumenical movement in South Africa, as well as the broader South African society, was not fully answered in this article. This is a field that demands further studies. Suffice to say that in some aspects, there has been a learning curve, and in some areas the focus is still on how CoS has contributed to the dynamics in the South African context. In personal interactions, friendship has developed, and many lessons have been learnt. One can mention missionaries and other co-workers (including myself) who have had the privilege of living and working in South Africa for a number of years. The project Mission in Return did not develop into its full potential though. Within the twinning relations, many contacts have been made and these contacts will continue. This in itself, is an area for further investigations.

The article started off with a mention of a Church hymn. In the field of music and also other art forms, Sweden has probably gained more from South Africa, than vice versa. But, this, again, lies outside the scope of this article.

\section{References}

\section{Unpublished Material}

Annual Reports from Church of Sweden Mission from 1994 to 1997.

Missionaries' and co-worker's reports from 1993 to 2019. (The individual reports are referenced with the year of the report followed by a digit that differentiate reports from the same year.)

Report from the General Secretary of Church of Sweden to the Church Board, 2019.

\section{Books, Articles and Online Material}

Ahmat, Z. 2008. Crimes of the Great Denialist. Published in Mail \& Guardian

27 September 2008. Available at: https://mg.co.za/article/2008-09-27crimes-of-the-great-denialist (Accessed on 20 February 2019.)

Björck, G. 2014. Förändring av Missionssynen? Perspektiv på Svenska kyrkans mission 1945-2000 speglad av Ledning och Missionärer. Uppsala: Elanders Press AB. (Studia Missionalia Svecana, CXIV.) 
Church of Sweden Bishops' Conference 2007. A Pastoral Letter from the Bishops of the Church of Sweden about HIV from a Global Perspective. Available at:

https://www.svenskakyrkan.se/filer/A\%20pastoral\%20letter\%20from\%2 0the\%20bishops\%20of\%20the\%20Church\%20of\%20Sweden\%20about \%20HIV\%20from\%20a\%20global\%20perspective\%20(2007).pdf

(Accessed on 24 February 2019.)

Church of Sweden International Department 2013. Our Theology: A Lifeempowering Faith as our Driving Force. Uppsala.

Evangelical Lutheran Church in Southern Africa ELCSA Youth League Constitution. Available at:

http://www.elcsadurban.co.za/Home/Resources_-

_Constitutions_files/ELCSA\%20Youth\%20League\%20Constitution.pdf (Accessed on 24 February 2019.)

Fosseus, H. 1974. Mission blir kyrka. Luthersk kyrkobildning i södra Afrika 1957-1961. Stockholm: Verbum.

Försoningsgruppen. Available at:

https://www.forsoningsgruppen.se/index.php/om.html

(Accessed on 26 February 2019.)

Göranzon, A. 2010. The Prophetic Voice of the South African Council of Churches after 1990. Searching for a Renewed Kairos. Cape Town: Salty Print. (Studia Missionalia Svecana, CXI.)

Hermansson, M. 1999. Mission i Retur. Ett inslag i Svenska kyrkans mission.

Uppsala: Svenska Institutet för Missionsforskning. (Missio No 14.)

Johnsen, T. 2017. Erkänd historia och förnyade relationer: Perspektiv på försoningsarbetet mellan kyrkan och samerna. In Lindmark, D. \& O. Sundström (eds.): Samerna och Svenska kyrkan. Underlag för kyrkligt försoningsarbete. Halmstad: Gidlunds förlag.

Modern Solidarity - What Did We Learn from Southern Africa's Liberation? Popular Movements' Meeting 11-12 April 2008 - Sigtuna Folk high school. Available at:

https://www.liberationafrica.se/events/sigtuna 2008/report modern soli darity.pdf

(Accessed on 24 February 2019.)

Outrage. Rev. Fr. JP Heath. Available at:

https://outragemag.com/author/rev-fr-jp-mokgethi-heath/ (Accessed 21 February 2019.) 
Persenius, R. 2003. Preface. In Söderström, H., S. Bergman \& T. Bergman (eds.): The History of the Evangelical Lutheran Church in Zimbabwe 1903 - 2003. Uppsala: Uppsala stift.

Pew Research Center 2017. Religion \& Public Life. Gay Marriage Around the World. August 8 2017. Available at:

http://www.pewforum.org/2017/08/08/gay-marriage-around-the-world2013/ (Accessed on 26 February 2019.)

Resare, N. 2010. Mutor, makt och bistånd. Jas och Sydafrikaaffären. Stockholm: Natur \& Kultur.

Stellenbosch University. Faculty of Theology. MTh with a Focus on Gender and Health. 2015. Available at:

https://www.sun.ac.za/english/faculty/theology/Documents/Events/MTh \%20GenderHealth.pdf

(Accessed on 24 February 2019.)

https://doi.org/10.1044/leader.PPL.24022019.28

Strinnholm, S. 2016. Att be på riktigt. Om vänförsamlingars betydelse för församlingar i Svenska kyrkan Härnösands stift. Unpublished. BTh essay. Available at:

http://uu.diva-portal.org/smash/get/diva2:956314/FULLTEXT01.pdf (Accessed on 24 February 2019.)

Svenska kyrkan. 1986. Den Svenska Psalmboken med tillägg. Stockholm: Verbum.

The Christian Councils of South Africa and Sweden. 2009. Joint Declaration. In Brune, P. (ed.): The Gothenburg Process. Faith-based Advocacy for Disarmament. Uppsala: Life and Peace Institute.

Tutu, D., A. Feinstein, B. Forsberg, K.G. Hammar, A. Ek \& S. Walan 2012. Hiv/aidssjuka $i$ Sydafrika drabbas hårt av Jasaffären. Published in Dagens Nyheter 2012-02-01 Available at:

https://www.dn.se/debatt/hivaidssjuka-i-sydafrika-drabbas-hart-avjasaffaren/ (Accessed on 20 February 2019.)

Tyrberg, K-J. 2011. Berättelser från olika perspektiv. In Svenska kyrkans teologiska kommitté, Samiska rådet inom Svenska kyrkan. Rapport från Ságastallamat, en konferens om samerna och Svenska kyrkan, i Kiruna den 11-13 oktober 2011. Available at:

file:///C:/Users/andgora1/Downloads/e2c9363d-84a8-482a-98d9-

99e442b28714.pdf

(Accessed on 03 February 2019.) 
University of KwaZulu-Natal. 2014. Gender, Religion and Health Programme. Available at: http://notices.ukzn.ac.za/content/GetFile.aspx?id=9703 (Accessed on 24 February 2019.)

Uppsala stift. Vänkyrka i Zimbabwe. 2019. Available at:

https://www.svenskakyrkan.se/uppsalastift/zimbabwe (Accessed on 21 February 2019.)

World Council of Churches. 2013. Together towards Life. Mission and Evangelism in Changing Landscapes with a Practical Guide Edited by Jooseop Keum. Geneva: World Council of Churches.

Zimbabwe Council of Churches. 2009. Pastoral Letter to the Nation. Available: file:///C:/Users/andgora1/Downloads/c308b597-e2f9-486f-98637dbd82adf961\%20(1).pdf (Accessed on 24 February 2019.)

Anders Göranzon Lärare i homiletik Svenska kyrkans Utbildningsinstitut Uppsala Sweden anders.goranzon@svenskakyrkan.se 